\title{
EDUCATING FOR PROFESSIONALISM: \\ A NEW MILITARY FOR A NEW SOUTH AFRICA ${ }^{\mathrm{i}}$
}

\section{Lt Col Abel Esterhuyse, Department of Military Strategy Faculty of Military Science, Stellenbosch University}

\begin{abstract}
This article explores the role of education in professionalising the South African National Defence Force (SANDF) since 1994. The central thesis is that military education, training and development played a major role in bringing the pre1994 belligerent forces in South Africa together and blending them into a single, coherent, bureaucratised defence force. There is, however, reason for serious concern. The article first outlines the specific need for education in the SANDF since 1994. The second part provides an overview of the educational institutions in the SANDF, their programmes and the nature of education, training and development that are provided. The final section discusses the most salient factors that have influenced education in the SANDF over the last decade. Specific emphasis is placed on the lack of suitably qualified academic staff, the difficulty of educating soldiers in a second or third language, the lack of research and the presence of an institutional climate of anti-intellectualism.
\end{abstract}

\section{Introduction}

In 2004, South Africa celebrated ten years of democracy and the SANDF looked back on ten years of 'defence in a democracy' as outlined in the 1996 White Paper on Defence. The White Paper aimed, inter alia, at the restoration of the military to its rightful place in society. This required the simultaneous implementation of two seemingly divergent notions. The SANDF had to become

\footnotetext{
${ }^{i}$ Edited version of a paper that was read at the 2005 Annual Meeting of the Society of Military History on "The Rise of the Military Profession" in Charleston, South Carolina, 24-27 February 2005. The author wishes to extend his gratitude to Prof Dan Henk (U.S. Air War College); Prof Kobus Kotze; Lt Col (Dr) Francois Vreÿ (Faculty of Military Sciences, Stellenbosch University) and Prof Lindy Heinecken (Department of Sociology and Anthropology, Stellenbosch University) for valuable feedback and critical comments. The author, however, accepts sole responsibility for the article.
} 
less prominent in policy-making and societal processes, while at the same time restore its legitimacy within the South African society. Both these notions are contained in the traditional understanding of military professionalism. This was no easy task as the former South African Defence Force (SADF) had featured prominently in the implementation of the policy of apartheid and was consequently politically contaminated. ${ }^{1}$

Since its inception in 1994, the SANDF has focused almost exclusively on structural issues. These included the integration of pre-1994 belligerent forces into a cohesive defence force; the transformation of the military to reflect the democratic ethos of society; organisational restructuring to fit a declining defence budget; and doctrinal changes to reflect South Africa's new role on the African continent. The doctrinal changes, in particular, were augmented on the basis of a rising need in the SANDF to understand South Africa's contemporary geo-strategic position and role, which included an understanding of Africa, of South Africa's interests and those of its partners in the New Partnership for Africa's Development (NEPAD) and the African Union (AU), and of the threats to these interests and the constraints on South Africa's ability to deal with the threats. All of this took place against the background of a realisation of the importance to balance racial representivity in the SANDF, while retaining expertise and professionalism.

South Africa is one of more than 40 countries that have gone through political transformation in the last two decades. The majority of these transformations, from Russia to the Philippines and Chile, are characterised by a transition from some form of authoritarianism to democratic rule. Most authoritarian regimes lack the kind of civil-military relations characteristic of developed states of the Western World; a high level of military professionalism and recognition by military officers of the limits of their professional competence. ${ }^{2}$ This 'objective civilian control' includes a recognition and acceptance by military officers of an area of professional competence and autonomy for the armed forces. ${ }^{3}$ Thus, Huntington argues, successful political transitions are often closely linked to recognition of the interplay between military competence, military professionalism and sound civil-military relations. ${ }^{4}$ This article explores the way in which military education was used in South Africa to professionalise its armed forces. Firstly, this necessitates a brief overview of the nature of officer education.

\section{Facing the challenges of education in the South African military}

Professional military knowledge is the product of the interplay between military training experience and education. This interplay is rooted in a process of 
progression: from the making of lieutenants and the making of colonels to the making of generals. The making of lieutenants is characterised by introductory military training, a process of military socialisation, and some form of education. The education is most often general scientific in nature. The making of colonels is a combination of tactical training and professional military education to inculcate officers with the broad doctrinal understandings needed for command and staff in the tactical and operational realms. The making of generals encompasses an educational process that includes elements of both professional military and general scientific education in preparation for the politico-military environment in which generals find themselves. It is thus interesting to note that the SANDF uses the notion Education, Training and Development (ETD) to denote all the schooling activities in the South African military.

Education plays a fundamental role in the interplay between the military and broader society. As Showalter ${ }^{5}$ explains, education provides credibility at all levels of society at large as a mark of merit. In short, education in the SANDF - and with that the role of the military as an educator - underpins the standing of the military in the eyes of the broader South African society. This is an extremely important notion in South Africa, since unequal access to jobs and education and, consequently, extreme levels of income inequality were among the defining characteristics of apartheid. ${ }^{6}$ As a result, the provision of military education underpins the success of the SANDF in the same manner that the provision of education in general lies at the heart of a successful 'new South Africa'. At the individual level, a military career consists of rotation between operational and staff assignments. This rotation is rooted in the duality of a military career - the need for bureaucratic and professional expertise, and for action and reflection. Janowitz ${ }^{7}$ postulates that the military career would be better described as a progression of educational experiences, as student and teacher, interspersed with operational assignments. As an officer progresses in the military hierarchy, different training and education opportunities are offered at prescribed intervals to develop new skills and gain new perspectives. This implies a particular progression, correlation and cohesion in the education of officers throughout the whole of their careers.

Like most new democracies, the first democratic government in South Africa had to deal with a vast array of problems. New democracies often have to establish their general authority with the public; draft new constitutions; establish competitive party systems and democratic institutions; transform their economies to promote growth while inflation and unemployment are managed; reduce fiscal deficits; limit crime and corruption and curb tensions and violence among ethnic and religious groups. ${ }^{8}$ South Africa also had to face the HIV/Aids pandemic in a badly 
distorted society. Though these problems affected the military, none was of a specific military nature. ${ }^{9}$

The 'new South Africa' in particular did not face any significant conventional threat from either the international or domestic environment. Political, security and strategic thought and approaches tended to be idealistic in nature. There was a deliberate effort to steer away from a more competitive, realist, nationalistic outlook on domestic and international security affairs. Such an approach was understandable, given apartheid South Africa's history of the securocratisation $^{10}$ and militarisation of society and the destructive role of the apartheid government's security forces in the region. ${ }^{11}$ A large number of policy documents outlining the government's approach in dealing with security and military affairs have been produced since 1994. Most noticeable are the White Paper on Defence, White Paper on Defence Related Industries in South Africa, and White Paper South African Participation in International Peace Missions. A human security approach and the idea of non-offensive defence or non-threatening defence underpinned most of these documents. ${ }^{12}$

In contrast with this idealistic security thinking was a process of military renewal through the procurement of an array of major new weapons systems for the SANDF - the so-called Strategic Defence Package (SDP). ${ }^{13}$ This can be seen as recognition by government that irrespective of South Africa's very idealistic policy outlook on peace and security, "bad times will return". ${ }^{14}$ The underlying argument is that even peace has to be secured and that the best way to do this is to have professional, competent military forces at hand. There are rare occasions when force, and only force, can satisfy the security needs of a nation. From this perspective, force is like an airbag in your car - generally unneeded but life preserving on that one day in a thousand when the peril is truly acute. ${ }^{15}$ This need for and role of professional military forces in society are not always understood in Africa. ${ }^{16}$ Yet, the SDP remain very controversial and responsible for a huge public discourse. Underlying this discourse is the importance of a culture of transparency, and of free and open debate of security, defence and military matters in a democratic society. In any democratic society - new ones like South Africa in particular recognition of the importance of a culture of understanding, articulating and debating of the complexities of security, strategic, defence and military affairs is critical.

Not only should the military be an important locus of such a discourse; it should also be an active participant in the debate. The military will only develop an understanding for the importance, the need and the nature of such a debate - and 
also participate in it - if the officer corps has an intellectual understanding of its role in society. The SANDF was successful in the lobbying process for support of the SDP in the initial period after 1994. There was also a lively interaction between the SANDF and non-governmental think tanks like the Pretoria based Institute for Security Studies. Yet, its general interaction with the broad South African public, specifically through the media, was nothing but a disaster. ${ }^{17}$ Since the completion of the White Paper on Defence and the Defence Review "consultation with civil society has declined". 18

The South African Constitution adopted by Parliament on 8 May 1996 states: "The security services must act, and must teach and require their members to act in accordance with the Constitution and the Law, including customary international law and international agreements binding on the Republic" (emphasis added) [Section 199(5)]. It is obvious that the Constitution requires SANDF members to have a higher understanding of their operating environment than that which is normally provided through training. The South African White Paper on Defence $^{19}$, under a heading titled, Education and Training, indicates that education and training are cardinal means of building and maintaining a high level of professionalism in the armed forces. The White Paper, furthermore, stipulates that the SANDF shall be a balanced, modern, affordable and technologically advanced military force, capable of executing its tasks effectively and efficiently. The need for the SANDF to be a well-educated armed force is implicit in these provisions.

The White Paper also requires from the Defence Force to design and implement a civic education programme on defence in a democracy to "instill respect amongst military personnel and other members of the DOD for the core values of a democratic South Africa through appropriate education and training". ${ }^{20}$ It is important, though, to understand that this programme was not treated as a separate alone standing entity. The programme formed part of the existing training and educational programmes of the defence force. It is therefore very difficult to form an opinion as to the success of the programme. There is reason to believe that the majority of military members have embraced the democratic ethos in the country. Whether this is the result of this required programme, the general democratic ethos in the country or the normal military courses are almost impossible to say.

The demands placed on the leaders of the SANDF since its inception have grown in scope and intensity. These demands extend well beyond the traditional responsibility of preparing forces for and executing combat and other types of operations. Since 1994, the SANDF has had to deal with unique structural and 
strategic challenges. The brief history of the post-apartheid period in South and Southern Africa has reinforced the need for military officers who are not only technically and tactically proficient, but also well versed in strategy, history, geopolitics and, in particular, in the complex cultures and politics of the African continent.

\section{The historical legacies of the integrated armed forces in search of professionalism}

In the SANDF, as in its predecessor, the $\mathrm{SADF},{ }^{21}$ education has always been perceived as a 'nice to have'. Education has never been an integral part of the career of an officer to the extent that it was institutionalised and thus a requirement for promotion to a higher rank. By 1994, the SADF was the largest, most up-todate, and most sophisticated military force in Southern Africa. ${ }^{22}$ In essence, though, the SADF was a war-fighting force with an emphasis on operational and tactical matters, ${ }^{23}$ or, as Seegers explains: "military experience counted more than intellectual or staff ability" and "the action was in the line". ${ }^{24}$ During the 1970s and 1980s, soldiers were needed "on the border" or "in the bush". The SADF favoured tactical training and experience. Only a few members of the SADF (the generals sitting on the State Security Council, in particular) involved themselves with the broader political and economic challenges of the Apartheid State. For the greater part of the SADF it was a matter of focusing on the immediate operational and tactical challenges with which they were confronted. This attitude was reflected in the findings of the Truth and Reconciliation Commission in South Africa, led by Archbishop Desmond Tutu. The SADF had no real culture of military education. The Military Academy, for example, did not even offer courses in disciplines such as strategy and defence policy until 1991. In fact, no subject of a military professional nature, such as Military Strategy of Military History, was compulsory for any student. ${ }^{25}$ Officers who were seen as being too academically inclined were considered unsuitable for command positions. ${ }^{26}$

In 1980, Heitman published an article titled "Is the Army Literate?" in Militaria. $^{27}$ It was concluded that the SADF neither read nor wrote and was suffering from mental stagnation. He identified three possible reasons for officers in the SADF neither reading nor writing: the bureaucratic process to obtain security clearance for anything written; the absence of suitable local military journals; and the absence of any professional, financial or other form of incentive. In the end, the emphasis on training and experience in the SADF resulted in a very tactically minded force. The fact that the SADF was a conscript force reinforced this tactically mindedness. ${ }^{28}$ Thus, SADF officers were in general very politically 
naive. ${ }^{29}$ And because officers did not read or write, professional knowledge was not widely shared within and outside the SADF. In fact, it had very little depth. Not much has changed in this regard over the last ten years, although there are a noticeable number of officers who have busied themselves with academic studies at tertiary institutions throughout the country. ${ }^{30}$ Sad to say, the majority of these studies fall outside the realm of the study of security, strategic and military affairs. And, like its predecessor, the SANDF has also not institutionalised education as an integral part of the careers of its officers. Academic qualifications are not held in high regard and are not a requirement for promotion. ${ }^{31}$

But what about the non-statutory forces ${ }^{32}$ that fought the Apartheid state's military machine and became part of the SANDF after 1994? Most of these nonstatutory forces came from a revolutionary environment. Revolutionary wars by nature necessitate a political and strategic orientation. Liebenberg, for example, asserts that revolutionary soldiers "have a broader understanding of the political world". ${ }^{33}$ Revolutionaries do not become politically and strategically minded through training and tactical experience in war-fighting. Worldwide and throughout history, revolutionary armies have been known for their political education or, rather, political indoctrination. Given that military expertise is the result of the interplay between military experience, training and education, military education through political indoctrination - alone does not epitomise real professional military knowledge.

The ideological basis of the struggle against apartheid included a strong element of Marxism that was reinforced by training in communist countries. ${ }^{34}$ The guerrilla forces that were integrated into the SANDF were highly politicised, ${ }^{35}$ and very 'streetwise' ${ }^{36}$ For decades, part of their ingrained culture had been to resist, defy, test, protest and challenge official authority. Liebenberg argues that these soldiers were much more analytical, creative, adaptive and pragmatic. ${ }^{37}$ Perlmutter and Bennet explain the challenge that revolutionaries like these pose to a professional armed force:

The dilemma of the military in postrevolutionary times is that the revolutionary soldiers must be politically disarmed and professionally rearmed. The transition for revolutionary soldiers is difficult, especially for those officers who become romantic and nostalgic for the heady revolutionary days. Soldiers, like party ideologists who find themselves bored and impatient with the mundane chores of government, become political liabilities for the regime. On the whole, government finds alternative roles for them; but if they insist on continued military service, 
they must submit to the professionalization and routinisation process that engulfs the military in the postrevolutionary period. Ideally, the postrevolutionary army should become routinised, depoliticised, and professionalised. $^{38}$

Some of these non-statutory force members did received military training in some cases education - in various places in the world. ${ }^{39}$ This at least provided them with a broader world view than most of their colleagues from the SADF. Also, some of the members of these forces gained tactical experience in fighting revolutionary wars in places like Angola. The problem, outlined by Perlmutter and Bennet, was that these forces in particular were not used to operating as a bureaucratic armed force. Thus both the former statutory and non-statutory forces that were brought together in the SANDF had to be "politically disarmed and professionally re-armed".

The need for education since 1994 has, however, been rooted in the requirement to unite and build a single cohesive defence force, to redress the wrongs of the past and to restructure and transform the defence force for the future. These, primarily, were the needs that brought members of the different pre-1994 belligerent forces together in the classrooms of the newly created SANDF. It was primarily in the classrooms of the different training and educational institutions that most of the members of the pre-1994 belligerent forces were introduced to each other for the first time. It was in these institutions that they were first confronted by their fears, where prejudices and old views were challenged and where a new team spirit was developed. The training and educational institutions, therefore, needed to be robust enough to not only provide training and education in the traditional sense of the word. They first had to address and facilitate a completely different set of dynamics before and as part of the educational process. The South African Military Psychological Institute played a cardinal role in helping these institutions to deal with these processes. ${ }^{40}$ This begs the question: what was the nature of the schooling provided by the SANDF since 1994 ?

\section{The process of military professionalism: understanding education, training and development in the SANDF}

Like most defence forces, the SANDF provides a wide variety of education and training opportunities to its officers. There is recognition that education, training and experience are all important in the making of an officer, but that this does not necessarily take place at the same institution and at the same time. 
The framework used in this discussion reflects the kind of training and education that are provided to officers in most armed forces of the world.

\section{Providing basic professional military education and training}

The first step in the process of the making of professional military officers is the provision of a basic, professional military education and training - 'the making of lieutenants'. ${ }^{41}$ Three processes underpin the making of lieutenants. Firstly, candidate officers need to embrace the military ethos and become military minded. They ought to think and act like soldiers and officers. This necessitates a very strong emphasis on military socialisation - and emotional maturity. ${ }^{42}$ The example of mentors and other role models within the military is of critical importance in this regard. Secondly, candidate officers, whether in the army, navy or air force, have to be prepared for their primary function as military professionals: armed combat. This requires an emphasis on the training domain to equip them with the necessary military (fighting) skills to operate as junior leaders in their respective geographical domains. Thirdly, candidate officers need to develop an understanding of the military profession and the proper role thereof in a modern democratic society. This necessity is rooted in military education.

In the SANDF, the first two processes are the primary focus of the Naval College and the Air Force Gymnasium and Army Gymnasium. ${ }^{43}$ At present, one year is utilised for the initial military training and socialisation. At the Army Gymnasium in particular, the emphasis is on the provision of a solid infantry grounding as a foundation for corps training. Being military minded also implies an understanding by candidate officers of the notion of 'defence in a democracy' and of "developing the political and ethical dimensions of military professionalism" as outlined in the South African White Paper on Defence. ${ }^{44}$ Insight into these higher order conceptions can only be acquired through academic study and this underpins the vital role of academic studies at the South African Military Academy. After one year of military training and socialisation at the junior leader training institutions, the candidate officers are transferred to the Academy where the bulk of their time is taken up by academic (university) studies. Ideally, officers should graduate with a first degree and a commission as a lieutenant in a particular service after one year of training and three years of study. (See figure 1.) 
Figure 1:

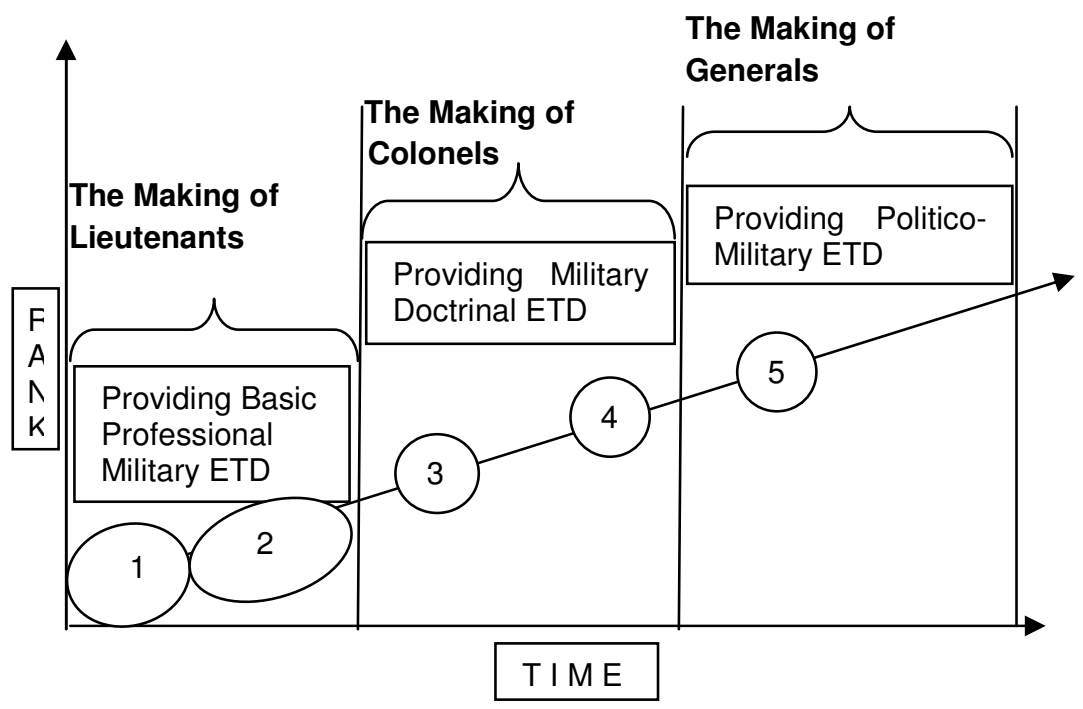

1. Naval College and the Air Force and Army Gymnasiums

2. South African Military Academy

3. Service Colleges: Junior Command and Staff Programme

4. South African National War College: Joint Senior Command and Staff Programme

5. South African National Defence College: Executive National Security Programme

The duration of a specific individual's tenure of study at the Academy, however, depends on his own record of achievement. The ideal is that as many as possible of the candidate officers should stay at the Academy for three years of study. After three years, the potential officer is commissioned with a long-term contract from the Department of Defence. If not, a student may choose or be directed towards a one-year certificate in military studies at the Academy with an accompanying short- or medium-term contract. In such a case, completion of studies through correspondence and switching to a long-term contract remains a possibility. $^{45}$

The role of jointness in the making of lieutenants in the SANDF has to be emphasised. Whereas the training and initial socialisation is service and even corps specific, education at the South African Military Academy is a joint endeavour. 
Unlike most of the world's armed forces, South African officers are bred in jointness. The advantages and disadvantages of such an approach are open for debate. The emphasis on jointness, for example, has an erosive effect on the service specific military socialisation during the first year of training. This is an especially thorny issue considering the fact that the Military Academy has an academic, rather than a regimental ethos.

What has changed since 1994? Firstly, there was a deliberate effort by the different services to develop a single curriculum for the first year of training presented to the candidate officers at the different institutions. This single curriculum makes provision for the culture and service specific training of each service, but ensures that the same standard is adhered to throughout. ${ }^{46}$ Secondly, whereas, in the case of the Army, each corps school used to train its own officers, a single training institution - the Army Gymnasium - was given responsibility for the initial training of all the candidate officers of the Army after 1994. Thirdly, since the recruitment of the Defence Force is now specifically directed towards communities that were to some extent excluded from service in the past, there is a deliberate effort to give people from previously disadvantaged communities an opportunity to acquire a basic tertiary education. Within the SANDF there has, therefore, been an increasing need for and emphasis on education since 1994. As a developmental tool, education has become increasingly important. In some circles, there are even visions of a first degree as a prerequisite for entrance into the officer corps. ${ }^{47}$

\section{Providing military doctrinal education and training}

Military doctrine is the bridge between thought and action. It interprets the higher conceptualisation of war, embodied in strategic theories and operational plans, into working guidelines for action - 'standard operating procedure'. ${ }^{48}$ The purpose of military doctrinal education and training is to give officers all the competencies they need to deploy and employ military formations from a platoon to, in the case of South Africa, a division. The aim is to school officers to be tactically and operationally minded and to operate with ease in these realms. The doctrinal schooling of officers culminates in the ability of the officer to be a campaign planner and an operational commander. Crackel refers to officer development at this level as the 'making of colonels'. ${ }^{49}$ Important to understand, though, is that the making of a colonel starts as soon as the officer receives his commission - even before that.

Two institutions are primarily responsible for doctrinal schooling in the SANDF: the different service colleges ${ }^{50}$ and the South African National War College. (See Figure 1) The different service colleges are the main tactical training 
institutions in the SANDF. These colleges have a service specific focus in their training, since the aim is to give officers a thorough schooling in the tactics of land, maritime and air warfare and the use of land, naval and air power in military operations other than war (MOOTW). In the case of the Army, the course is split into a distance education phase of six months and a residential phase of twenty-four weeks. ${ }^{51}$ Officers attending the Junior Command and Staff Programmes are senior majors - lieutenant-commanders in the case of the Navy. ${ }^{52}$ The newly created National War College, on the other hand, presents a twelve-month Joint Senior Command and Staff Programme to lieutenant-colonels. The programme focuses on campaign level warfare and prepares students to be operational commanders. ${ }^{53}$ To be specific: the programme aims at "preparing selected officers for senior appointments at the operational level by developing their command, staff and analytical skills, and by broadening their professional understanding of singleservice, joint and combined operations, the management of defence and the wider aspects of conflict". ${ }^{4}$

The biggest and most obvious change since 1994 has been the creation of the National War College, officially opened on 28 January 2002, and the introduction of the Joint Senior Command and Staff Programme. ${ }^{55}$ Whereas each service previously presented its own 'senior' staff course, the emphasis at the National War College is on jointness. The 'senior' staff course in 1994, inherited from the former SADF, had an almost exclusive focus on the tactical level with an accompanying emphasis on training. Not only has the emphasis since 1994 shifted towards the operational level of war, but the curriculum now also reflects a developmental and educational methodology. The study of military history features very prominently in this regard. ${ }^{56}$ The greater emphasis on education necessitated a greater input from academics into the development and presentation of the course. A military historian with a doctoral qualification has been appointed at the South African Army College since 1997. He is not only responsible for teaching military history at the National War College and the Army College at present, but also facilitates an annual staff trip to the most important battlefields of the Anglo-Zulu and the Anglo-Boer Wars in northern KwaZulu-Natal for National War College students. $^{57}$

Two other important changes are also noticeable. The one is the provision for military bureaucratic education in the curricula of the different colleges. In the past the emphasis was almost exclusively on warfighting and other military operational issues. In the case of the National War College, this has been formalised through an agreement with the Tshwane University of Technology concerning the presentation of a diploma in military management as part of the Joint Senior 
Command and Staff Programme. ${ }^{58}$ A second very important change has been the interaction with foreign staff colleges from all over the globe, Africa in particular, since 1994. These interactions not only had a formative influence on the curricula of the colleges; it also led to the exchange of students and directing staff. This has become an important part of military diplomacy in the SANDF, especially in its relationship with other defence forces on the African continent. ${ }^{59}$

\section{Providing politico-military ETD}

In most armed forces, the careers of officers up to the rank of colonel or navy captain are mostly confined to the military environment. As generals or admirals, however, they also have to operate in the politico-military sphere. Thus the purpose of politico-military schooling is to assist officers to prepare themselves for high command. Whereas basic military and doctrinal schooling is directed towards the making of lieutenants and colonels, politico-military education aims at the making of generals. The making of generals focuses on the need for senior officers to become strategically and politically minded. They have to be prepared to work with leading defence officials and political office bearers in managing and controlling the country's military resources in accordance with the security needs of the country and in subordination to the polity. ${ }^{60}$

The South African National Defence College presents the Executive National Security Programme to colonels and navy captains earmarked for promotion to general or admiral. (See Figure 1.) Prior to the introduction of this programme, the National Defence College presented the Joint Staff Course aimed at "educating, primarily, senior SANDF officers, at the military strategic level". ${ }^{61}$ Due to the changed circumstances in South Africa, a need was identified for officers to be exposed to the national strategic level and to become acquainted with the functioning of other state departments, foreign defence perspectives and the civilian sector. The Executive National Security Programme focuses on national security issues in a regional and African context, against the background of global issues. The central theme, however, is national security. ${ }^{62}$

Though the decision to migrate from the Joint Staff Course to the Executive National Security Programme was sound, certain shortcomings emerged in recent times. The first is rooted in the difference between an educational and a training approach in the presentation of the programme. To be specific, the programme does not make provision for an active educational process and students do not necessarily go through a process of internalising newly acquired knowledge. At the same time, it should be emphasised that the Executive National Security Programme is an excellent compact programme, comparable to similar programmes 
elsewhere. The problem concerns the way in which it is presented, since the internalisation of knowledge is time intensive. Compared to similar programmes presented elsewhere, there is not sufficient time to debate the issues addressed to the extent that is required for analysis. Students need sufficient time to debate, disagree, argue, criticise and adjust opinions with regard to particular issues. Also, not enough emphasis is placed on the cultivation and development of a personal informed opinion. Though the scope of the programme is extensive its academic depth is under suspicion. ${ }^{63}$ This particular point is underpinned by the lack of formal processes of assessment. In recent years, nomination to attend the programme is all that was needed to successfully complete the programme. ${ }^{64}$ As Van Creveld explains, career-conscious officers are not "necessarily motivated to serious study in an institution where there is no competition and from which everybody who enters is certain to graduate". 65 The National Defence College, however, became aware of these shortcomings and has ventured into a process of making some necessary adjustments and changes.

A second problem concerns the level at which the programme is focused. At present, the National War College focuses on the operational level of war in its presentation of the Joint Senior Command and Staff Programme, whilst the Defence College focuses on national security in the presentation of the Executive National Security Programme. It is clear that the military strategic level is not addressed in any depth. Whether this ought to be the responsibility of the National War College or the National Defence College is open to debate. The issue is further complicated by the fact that the average officer has already spent a vast amount of time on formal training and education, and, secondly, that there is a need to extend the time spent on the Executive National Security Programme. Thus not only is it not clear where the responsibility for military strategic education should be located, but where to find the time to address the dilemma is also a problem. Taking into account that the military is primarily responsible for the military slice of national security, the military strategic level of war is not something that can be discarded or overlooked. The geo-strategic tendencies that unfolded worldwide since 9/11, including the conflicts in the Middle East and further afield, suggest a return to the more traditional understanding of security, with the military taking a more prominent position in scholarly focus. But more than that, though it is important for officers to understand the higher order conceptions of security, their main business remains the role of the military in addressing the security needs of society. Military strategic issues can never be neglected by the military. 


\section{Factors influencing and characterising education, training and development in the SANDF}

It is not easy to outline all the factors that influence education and training in a particular armed force and time frame. There are a number of very definite considerations, some more obvious than others, that have influenced education in the SANDF over the past ten years. It should be noted, however, that it is difficult to determine the precise extent to which these factors have influenced the educational and training system in the SANDF. The list of influencing factors is also far from complete.

The first real challenge is the use of the term ETD - Education, Training and Development. Grouping these different notions together in one organising concept gives rise to the danger that neither training, nor education or development is done well. In fact, most of the senior 'ETD institutions' - the exception being the Military Academy - at present aspire towards the development of an educational capacity. Most do it through outsourcing of the academic component of their programmes. This means that they don't rely on their own capacity to educate. It also implies that the attributes that are needed for an educational ethos are lacking. In fact, most educational institutions in the SANDF at present lack the ability to present students with a real educational experience. One senior SA Army general, for example, describes the nature of training and education in the SANDF as "mechanistic" and pointed out that it is "mark sheet driven". ${ }^{6}$

A further noticeable challenge is the lack of academically qualified directing staff. Most of the officers serving on the directing staff of educational institutions - the Military Academy once again being the exception - do not possess suitable post-graduate academic qualifications. Most of the SANDF's educational institutions are, therefore, faced with a situation of institutional paralysis: a willingness to be an academic institution, but an inability to become that. The directing staff at these educational institutions at present also does not busy themselves with the kind of activities with which academics normally attend to teaching and research, to be specific. It has been said that they are nothing more than glorified administrators and bureaucrats, their days being filled by all kinds of organising activities to keep the different programmes running. ${ }^{67}$ This leaves them with very little time for constructive research and development, the lifeblood of any academic institution. Thus there is a real danger that the SANDF's schooling institutions are neither institutions of training nor of educational excellence. 
Budgetary constraints will always remain a challenging reality in the training and educational environment. In the SANDF this is an especially thorny issue. The South African national budget has a clear welfare focus aimed at increasing the standard of living of the average South African. Defence spending was one of the areas that were eroded to finance the welfare-focused budget. The Department of Defence budget allocation for the Financial Year (FY) 89/90 was $4.6 \%$ of the Gross National Product (GNP). In the FY 94/95 it was reduced to 2.5\% and in the FY 00/01 it was further reduced to $1.6 \%$ of the GNP. ${ }^{68}$ The real challenge was not how to deal with the shrinking budget but, rather, how to cope with the rising operational commitments of the SANDF in view of the smaller budget. This led to a situation where the financial allocations to the different internal SANDF structures were minimised in order to keep up with operational commitments. In the FY 04/05 the Joint Training Formation received only 75 percent of its required budget ${ }^{69}$ and in the FY $05 / 06$ only 81 percent of the required funding. ${ }^{70}$ Thus there is no doubt that the erosion of the training and educational budget in the SANDF over a period of time has affected the quality of the training and education that are provided.

Another factor to consider concerns the major military doctrinal changes that have influenced training and education. Three changes featured prominently in this regard. ${ }^{71}$ Firstly, the recognition that future military operations will require an increased joint and combined focus, i.e. operations in which the ability of more than one of the services and more than one country will be needed. An emphasis on jointness always has a positive effect on the problem of inter-service rivalry. This, for example, led to the creation of the National War College at which not only officers from different services are trained together, but where the presence of foreign officers became the rule rather than the exception. Secondly, the defence force has had to adapt itself to project force over very great distances. Strategic and operational force projection was and still is a very unique challenge in the African theatre of operations with its lack of infrastructure. The extent to which this challenge has influenced military thinking and education, if at all, is not clear. Its influence on the SANDF's ability to conduct operations is, however, beyond any doubt. Lastly, the need for the use of military force in so-called non-traditional roles became important and was reflected in new doctrine and in the curricula of the training and educational institutions. Indeed, this became a debated issue, even in academic circles, with questions asked about how primary the primary mission of the SANDF really is. ${ }^{72}$ It has since been accepted that the secondary roles $^{73}$ of military forces - commonly known as military operations other than war (MOOTW) - will be an important part of the job description of armed forces in future. In particular, the use of military power not to create peace, but to keep the peace that 


\section{7}

has already been created, features very prominently on the operational agenda of the SANDF in Africa.

The birth of the New South Africa with its roots in the negotiated settlement of 1994 has had a profound impact on the nature of military authority and discipline. This change and impact was brought about (inter alia) by the integration of the different forces and their accompanying cultures in the SANDF. There has been a clear move away from authoritarian domination towards a reliance on explanation, persuasion, negotiation and group consensus. ${ }^{74}$ Observed from within the organisation and compared to the period immediately before 1994, members of the SANDF at present appear to be more inclined to be more considerate and to practice caution and prudence to avoid misunderstandings, tension and ill feeling. On a personal level they are called upon to use diplomatic skill, to seek compromises by means of consensus and to be tolerant of others. These are also the attributes that underpin a true educational and professional ethos. It encourages debate, critical questioning and diverse views, and challenges old paradigms. However, this approach to discipline and education seems to be questioned within conservative circles among both the former non-statutory and the statutory forces.

Another factor that has influenced the nature of training and education in the SANDF was the acceptance of English as its language of command. ${ }^{75}$ The decision was clearly based on operational needs and the necessity to have one language as a command and operating language. This need is understandable and there is no reason to question the decision. It is important, however, to recognise that a multilingual environment will always complicate training and education. This is especially true in a country that has eleven official languages. ${ }^{76}$ To train and educate people in an environment where English is neither the first language of the trainees nor of the trainers and educators, must have a detrimental impact on the quality of the education. Almost all the instructors, directing staff and educators that were interviewed, expressed the need for the development of English language skills, particularly writing skills, in the SANDF.

Lastly, quality training and education is not possible without research. Quality research forms the bedrock of good quality training and education. Research is being done in a number of centres and organisations within the SANDF. One, for example, is the Centre for Military Studies at the Military Academy, though it should be noted that, for a variety of reasons, the research output of the Centre for Military Studies has declined remarkably over the last number of years. ${ }^{77}$ The real problem, however, is the absence of a culture of research in the SANDF. As in all other defence forces, the officer corps of the SANDF experiences interplay between 


\section{8}

doers and thinkers. ${ }^{78}$ In the SANDF, however, the operationally inclined culture that was inherited from the SADF has been enforced by a number of factors. There is still no journal that would encourage officers to write on and debate doctrinal and other issues relevant to the military. ${ }^{79}$ There is also still no incentive for officers to engage in serious research and writing, and 'security' is still a controversial issue. ${ }^{80}$ There is furthermore no co-ordinating body and budget for research in the SANDF. Also, academics in the Department of Defence sometimes experience interference in the dissemination of their research outputs. Specifically, this problem has in some instances been experienced by academics at the Military Academy.

The result is that most of what has been written about the SANDF was done by (sometimes uninformed) individuals outside the defence force. In principle, there is nothing wrong with academics and other researchers outside the military writing about the SANDF. A problem arises when most of the prescribed literature of a defence force is acquired from outside sources and officers do not debate the issues that concern the heart of their profession. The real problem seems to be the presence of anti-intellectualism in the SANDF. The deputy chief of the SA Army, for example, recently stated that reading - the basis for any form of research and intellectualism - is not "the in thing;" also there is no "habit of reading" in the South African military. ${ }^{81}$ One of the directing staff members of the National War College also asserts that the SANDF has some excellent training and educational centres, but periods between visits to these centres are times of intellectual death for the majority of officers. ${ }^{82}$

\section{Conclusion}

The SANDF has come a long way since its inception in 1994. The integration of the different pre-1994 military forces into one cohesive defence force has been a momentous achievement. The military was probably the single most important stabilising factor in South Africa during the transitional period. The fact that the military did not explode or implode is testimony of the seeds of professionalism in the different forces that were brought together. The SANDF was established on this platform of professionalism. The SANDF provided the institutional framework for the integration of the previously operationally minded members of the statutory and revolutionary minded members of the non-statutory forces. All these different groupings presented distinct challenges from a military professional, training and educational point of view. Thus the SANDF has only taken its first steps on the road to true professionalism. And, as most armed forces of the world will testify, it is a hard road to travel without an end in sight. 
Much time and vast resources have been spent on training and education in the SANDF over the past ten years. At a practical level, it was in the classrooms of the different training and educational institutions of the SANDF that most of the members of the former belligerent groups were first brought together in a formal environment. It was within these classrooms that the 'new' members of the SANDF were first introduced and came to know one another. Within the framework of training and education, prejudices had to be confronted and perceptions changed. Thus training and educational institutions in the SANDF provided the platform for the creation of a single cohesive armed force in South Africa. There is little doubt that the nature of the future of the SANDF will also be moulded primarily in the classrooms of its different training and educational institutions.

The SANDF, however, is very far from the dream of a truly professional force. There are educational challenges that the SANDF needs to address on its path to a higher level of professionalism. The most challenging in this regard is the antiintellectualism prevalent in the SANDF. This current anti-intellectual institutional climate impedes the transformation of the SANDF into a real learning organisation. Addressing the anti-intellectual climate in the SANDF will go a long way towards promoting education as the true vehicle for transformation and professionalism in the SANDF. An important first step in this regard would be to afford education a standing of its own - not to integrate it with training and development. The creation of academic faculties at the different colleges or at least to ensure that the directing staff is academically educated, will also be a positive contribution. These faculties should not be overburdened with organisational and administrative tasks, as is the case at present. Other important steps would be to broaden the interaction between the SANDF and the academic community and exchange of staff and students with foreign armed forces. The vision of an educated officer corps should also be pursued. An important first step in this regard would be to start at the lowest levels and optimise the role, capabilities and contribution of the South African Military Academy.

\section{References}

${ }^{1}$ R Griffiths, "South African Civil-Military Relations in Transition: Issues and Influences," Armed Forces \& Society 21, 3 (Spring 1995), 395.

2 SP Huntington, "Reforming Civil-Military Relations," in Civil Military Relations and Democracy, ed. L, Diamond \& MF, Plattner (Baltimore: John Hopkins University Press, 1996), 3.

${ }^{3}$ SP Huntington, The Soldier and the State: The Theory and Politics of Civil-Military Relations (Cambridge: Harvard University Press, 1957), 83-85.

4 "Reforming Civil-Military Relations," 5. 
${ }^{5}$ DE Showalter, “'No Officer Rather Than a Bad Officer': Officer Selection and Education in the Prussian/German Army, 1715-1945," in Military Education: Past, Present, and Future, ed. GC, Kennedy \& K, Nielson (Westport: Praeger, 2002), 56.

${ }^{6}$ A Handley, "The New South Africa, A Decade Later," Current History 103, 673 (May, 2004), 196.

${ }^{7}$ M Janowitz, The Professional Soldier: A Social and Political Portrait (New York: The Free Press, 1971), 126.

8 "Reforming Civil-Military Relations," 4.

${ }^{9}$ See for example the discussion by Lindy Heinecken on the influence of HIV/AIDS in the South African Military in L, Heinecken, "Facing a Merciless Enemy: HIV/AIDS and the South African Armed Forces," Armed Forces \& Society 29, 2 (Winter, 2003), 281 - 300.

${ }^{10}$ Every part of the daily existence in South Africa during these times was linked to the security of the country in general and the security of the apartheid regime in particular.

${ }^{11}$ AJ Esterhuyse, "Ten Years of Democracy and the Return of Bad Times: Studying Security, Strategic and Military Affairs in South Africa", Paper presented at the Congress of the South African Sociological Association in Bloemfontein, 28 June 2004.

${ }^{12}$ E Jordaan, "South African Defence Since 1994: Practising What We Do Not Preach", Paper presented at the 4th War and Society in Africa Conference presented at the South African Military Academy, Saldanha, 4-6 September 2003.

${ }^{13}$ See D Botha, "Offsetting the Costs of SA's Strategic Defence Package," ISS Paper 75 (July, 2003) for a discussion of the thinking that underpinned this procurement.

${ }^{14}$ CS Gray, "Villains, Victims, and Sheriffs: Strategic Studies and the Security for an Interwar Period," Comparative Strategy 13, 360.

${ }^{15} \mathrm{Ibid}, 354$

${ }^{16}$ Bjorn Moller of the Copenhagen Peace Research Institute (COPRI) outlined this problem in Africa while speaking to students at the South African Military Academy on 15 April 2003. Also see the discussion of 'undermilitarisation' in Africa in ML, Martin, "Operational Weakness and Political Activism: The Military in Sub-Saharan African," in To Sheathe the Sword: Civil-Military Relations in the Quest for Democracy, ed. JP, Lovell \& DE, Albright (London: Greenwood Press, 1997), 81-98.

${ }^{17}$ See L Heinecken, R Gueli, \& A Neethling, "Defence, Democracy and South Africa's CivilMilitary Gap," Scientia Military - South African Journal of Military Studies 33, 1 (2005), 119140; and AJ Esterhuyse, "The South African Armed Forces and the Media: A Difficult Marriage?," in War, Military and the Media from Gutenberg to Today, ed. ME, Ionescu (Bucharest: Military Printing House, 2004), 147-148.

${ }^{18}$ G Cawthra, "Security Governance in South Africa," African Security Review 14, 3 (2005), 100.

${ }^{19}$ Department of Defence, "Defence in a Democracy," South African White Paper on Defence (Pretoria: 1 Military Printing Regiment, Approved by Parliament on 14 May 1996), 10.

${ }^{20}$ Ibid.

${ }^{21}$ Until 1994, South Africa's armed forces were known as the South African Defence Force. Since 1994, these forces are known as the South African National Defence Force.

${ }^{22}$ J Winkates, "The Transformation of the South African National Defence Force: A Good Beginning," Armed Forces \& Society 26, 3 (Spring, 2000), 452.

23 AJ Esterhuyse, "Managament and Command in the SANDF: Changing Priorities", Paper presented at the 4th War and Society in Africa Conference at the South African Military Academy, 4-6 September 2003.

${ }^{24}$ A Seegers, The Military and the Making of South Africa (London: Tauris Academic Studies, 1996), 141. 
${ }^{25}$ Subjects with a military or military-related content that are presented at the Military Academy include Military History, Military Strategy, Military Technology, and Nautical Science.

${ }^{26}$ The Military and the Making of South Africa, 141.

${ }^{27}$ H Heitman, "Is the Army Literate?," Militaria 10, 1 (1980), 48.

${ }^{28}$ Hackett argues that in a conscript army junior and middle-rank officers spend so much time and effort in the training of conscripts in elementary military skills that sufficient attention is not always given to the study of more advanced techniques. See J Hackett, The Profession of Arms (New York: Macmillan, 1983), 135.

${ }^{29}$ A senior South African army general expressed this view. He rose to the rank of colonel in the former SADF. Interviewed at the South African Military Academy, 7 Dec 2004.

${ }^{30}$ Interview with senior SA Army general at the South African Military Academy, 7 Dec 2004.

${ }^{31}$ SB Links, "The Battle for Recognition," South African Soldier (June, 2001), 22-23, 37.

${ }^{32}$ None of the forces that fought the apartheid state were part of a bureaucratised professional national armed force. They were the armed wings of political movements: Umkhonto we Sizwe (MK), the armed wing of the ANC; the Azanian Peoples Liberation Army (APLA), the armed wing of the PAC; the KwaZulu Self Protection Force (KZSPF), the armed wing of Inkatha. Since 1994, these forces are referred to as the non-statutory forces.

${ }^{33}$ I Liebenberg, "The Integration of the Military in Post-Liberation South Africa: The Contribution of Revolutionary Armies," Armed Forces \& Society 24, 1, (Fall, 1997), 204.

${ }^{34}$ JA Higgs, "Creating the South African National Defence Force," Joint Forces Quarterly 25 (Summer, 2000), 48.

${ }^{35}$ L Heinecken, "South Africa's Postmodern Military: Adapting to the New Strategic and Political Environment", Paper presented at the First Cranfield University International Conference on Defence Management, Cranfield University, Shrivenham, United Kingdom, 2425 April 2003, 10.

${ }^{36}$ Interview with senior SA Army general at the Military Academy, 7 Dec 2004.

37 "The Integration of the Military in Post-Liberation South Africa: The Contribution of Revolutionary Armies," 204.

${ }^{38}$ A Perlmutter \& AV Bennet, Introduction to the Political Influence of the Military: A Comparative Reader, ed. A, Perlmutter \& AV, Bennet (London: Yale University Press, 1980). 23.

${ }^{39}$ Twenty-three nations hosted non-statutory force training, from nearby Lesotho to the Soviet Union and Cuba. See "Creating the South African National Defence Force," 48.

${ }^{40}$ Discussion with a senior officer of the Military Psychological Institute in Pretoria, 13 Sept 2004.

${ }^{41}$ TJ Crackel, "On the Making of Lieutenants and Colonels," The Public Interest 76 (Summer, 1984).

${ }^{42}$ B Burridge, "Post-Modern Military Education: Are We Meeting the Challenge?," Defence Studies 1, 1 (Spring 2001) xvii.

${ }^{43}$ In South Africa, the use of the term Gymnasium to describe military training units is based on the Afrikaans use of the word "gymnasium" to describe a secondary school. This is derived from the German tradition of the 1800 s to refer to a secondary school as a gymnasiun.

44 "Defence in a Democracy," 10.

${ }^{45}$ Interview with a former Commandant of the South African Military Academy, Pretoria, 8 June 2004.

${ }^{46}$ Project Centurion: SANDF C PERS/DPD/103/1/R dd 23 Feb 1999 - Tasking Instruction.

${ }^{47}$ The possibility of a first degree as a minimum academic qualification for entrance to an officer corps was raised by some SANDF officers who were interviewed. There is doubt, however, about the practicality of such a requirement. A senior SA Army general interviewed at the Military Academy on 7 Dec 2004 emphasised that it remains a long-term vision. 
${ }^{48}$ J Gooch, "Military Doctrine and Military History," in Occasional Paper No 30 - The Origins of Contemporary Doctrine, ed. J, Gooch (Camberley: Strategic and Combat Studies Institute, September 1997), 5-6.

49 "On the Making of Lieutenants and Colonels."

${ }^{50}$ The Naval Staff College is located in Muizenberg, near Cape Town, and the Army and Air Force Colleges are located in Thaba Tshwane, near Pretoria.

${ }^{51}$ Department of Defence, SA Army Training Formation, "Draft Curriculum: SA Army Junior Command and Staff Duties Course Residential Module," SA ARMY TRG FMN/103/1/8/1/2, (December 2003), 1.

52 Interview with members of the directing staff of the Army Junior Command and Staff Course, SA Army College, Thaba Tshwane, 7 July 2004.

${ }^{53}$ Interview with members of the directing staff of the SA National War College, Pretoria, 7 July 2004.

${ }^{54}$ F Siyongwana, "Flagship Military Institution of Learning Opens," South African Soldier (March, 2002), 29.

55 Ibid, 28 \& 29.

${ }^{56}$ Interview with members of the directing staff of the SA National War College, Pretoria, 6 July 2004.

${ }^{57}$ Interview with the Resident Military Historian of the SA Army College, Thaba Tshwane, 6 July 2004 .

${ }^{58}$ Interview with members of the directing staff of the SA National War College, Pretoria, 7 July 2004.

${ }^{59}$ Interview with members of the directing staff of the SA National War College, Pretoria, 6 July 2004.

${ }^{60}$ See the discussion on the need for this kind of education by DF Bletz, "Military Professionalism: A Conceptual Approach," Military Review LI, 5 (May, 1971), 9-17.

${ }^{61}$ F Siyongwana, "Executive National Security Programme: The Fourth to be Held at the SA Defence College," South African Soldier (September, 2001), 29.

${ }^{62}$ Ibid.

${ }^{63}$ A view expressed by a senior SA Army general. Interviewed at the Military Academy, 7 Dec 2004.

${ }^{64}$ This particular problem was highlighted by a number of senior officers who have completed the ENSP. It was also pointed out by academics that regularly lecture to the ENSP and some of the directing staff at the SANDC.

${ }^{65} \mathrm{M}$ Van Creveldt, The Training of Officers: From Military Professionalism to Irrelevance (New York: Free Press, 1990), 103.

${ }^{66}$ Telephonic interview with a SA Army general, 2 Aug 2005. He described education in the SANDF in Afrikaans as "meganies" ("mechanical") and "merkstaat verknog" ("mark sheet driven").

${ }^{67}$ This problem was pointed out during interviews with members of the directing staff at both the SA National War College and the SA National Defence College, July, 2004.

${ }^{68}$ BR Janssen, "Comply with the Demands of an Uncertain Environment," South African Soldier (July 2004), 38.

${ }^{69}$ South African Department of Defence, Joint Training Formation Level 2 Strategic Business Plans FY 2005/6 to FY 2007/8, Joint Training Formation (27 May 2004), 3.

${ }^{70}$ South African Department of Defence, Joint Training Formation Level 2 Strategic Business Plans FY 2006/7 to FY 2008/9, Joint Training Formation (20 April 2005), 4.

${ }^{71}$ AJ Esterhuyse, "The Death of Six Soldiers in the DRC: The SANDF on the Domestic Political Agenda," CIPS Electronic Briefing Paper 19/2004 (Pretoria: Centre for International Political Studies, 23 April 2004). 
${ }^{72}$ See for example the article by R Williams, "How Primary is the Primary Function?: Configuring the SANDF for African Realities," African Security Review 8, 6 (1999).

${ }^{73}$ Defence against external aggression is seen as the primary role.

${ }^{74}$ Interview with a senior SANDF officer, Bloemfontein, 28 June 2004.

${ }^{75}$ M Harmse, "The New Language Policy," Salut (June, 1998), 14-17.

${ }^{76}$ English is the first language of about $10 \%$ of the members of the SANDF. Interview with senior SA Army general at the Military Academy, 7 Dec 2004.

${ }^{77}$ This is clearly evident from an analysis of the annual reports of the Centre for Military Studies as well as the tendency to appoint very junior (black) academics with almost no research experience or output in research posts. This is done mostly because of the imperative of affirmative action.

${ }^{78}$ Doers - operationally inclined officers - and thinkers - academically inclined officers.

${ }^{79}$ South African Soldier is basically a corporate magazine, while Scientia Militaria, on the other hand, is a Department of Education accredited academic journal that publishes peerreviewed scholarly articles. There is an urgent need for a journal that is aimed somewhere between these two extremes in the genre of the Military Review published by the US Army General Command and Staff College.

${ }^{80}$ Department of Defence, CSANDF, "Uncontrolled Release of Information," Communication Instruction No 01/2000, CSANDF/CDCC/511/2 (August, 2000). Authorisation is required from the Minister of Defence "for the release of other forms of information like speeches, presentations, etc. at public seminars and all public appearances".

${ }^{81}$ J Jooste, "Keynote Address: Knowledge Management in the SA Army," Landward Defence Institute 1 (March 2003), 7.

${ }^{82}$ Interview with a member of the directing staff of the SA National War College, 6 July 2004. 